\title{
A Development of Ethanol/Percarbonate Membraneless Fuel Cell
}

\author{
M. Priya, ${ }^{1}$ A. Arun, ${ }^{1}$ M. Elumalai, ${ }^{1}$ S. Kiruthika, ${ }^{2}$ and B. Muthukumaran ${ }^{1}$ \\ ${ }^{1}$ Department of Chemistry, Presidency College, Chennai 600 005, India \\ ${ }^{2}$ Department of Chemical Engineering, SRM University, Chennai 603 203, India
}

Correspondence should be addressed to B. Muthukumaran; dr.muthukumaran@yahoo.com

Received 29 January 2014; Accepted 15 May 2014; Published 29 May 2014

Academic Editor: Francesco Paolucci

Copyright (C) 2014 M. Priya et al. This is an open access article distributed under the Creative Commons Attribution License, which permits unrestricted use, distribution, and reproduction in any medium, provided the original work is properly cited.

The electrocatalytic oxidation of ethanol on membraneless sodium percarbonate fuel cell using platinum electrodes in alkalineacidic media is investigated. In this cell, ethanol is used as the fuel and sodium percarbonate is used as an oxidant for the first time in an alkaline-acidic media. Sodium percarbonate generates hydrogen peroxide in aqueous medium. At room temperature, the laminar-flow-based microfluidic membraneless fuel cell can reach a maximum power density of $18.96 \mathrm{~mW} \mathrm{~cm}^{-2}$ with a fuel mixture flow rate of $0.3 \mathrm{~mL} \mathrm{~min}^{-2}$. The developed fuel cell features no proton exchange membrane. The simple planar structured membraneless ethanol fuel cell presents with high design flexibility and enables easy integration of the microscale fuel cell into actual microfluidic systems and portable power applications.

\section{Introduction}

The portable multifunctional electronic devices with highspeed operations need better energy storage and supply options that are capable of delivering increased power and energy density. An important metric in the development of converged electronic devices is the operating time becoming limiting with conventional battery technology. The currently available battery technologies appear to be approaching a performance plateau and seem insufficient to meet the needs of future devices. While portable fuel cells offer a better alternative as a battery possessing good potential to meet future needs, a number of technical challenges need to be resolved in them. As a result, several microfabrication techniques have been developed to increase the power density, because miniaturisation of fuel cell stacks and components are known to increase the electrochemically active surfacearea-to-volume ratio, which is an important condition for improving performance.

A novel microfabrication method-fabrication inside capillaries using multistream laminar flow-is used to construct a new type of fuel cell, which eliminates several of the technical issues that crop up when using proton exchange membrane fuel cells (PEMFCs), such as fuel crossover [1], membrane degradation, a long startup time, ohmic losses, size, fabrication, and water management $[2,3]$ limited durability of catalysts [4]. Furthermore, as MEAs are expensive components at present, the cell structure without the membrane provides two advantages: decrease of electrical resistivity in the cell and inexpensive material cost.

A membraneless fuel cell is a novel device without a membrane that converts chemical energy generated from a fuel and an oxidant into electric energy by means of oxidoreduction reactions. In membraneless microfuel cells, liquid reactants (fuel and oxidant) flow side by side in a laminar fashion in a single channel, not requiring a membrane for reactant flow. Anode and cathode electrodes are positioned on the channel walls opposite to each other and the mixing of fuel and oxidant in the channel occurs only by diffusion. Moreover, the chemical composition of the cathode and anode streams can be designed individually to optimise individual electrode kinetics as well as overall cell potential.

An additional advantage is that structures of membraneless microfuel cells are very simple and easy to miniaturise [5], so that light and stackable fuel cells can be fabricated with simple microelectromechanical systems (MEMS) $[6,7]$. The implications of flexibility and the performance of operating membraneless sodium percarbonate fuel cell (MLSPCFC) in 
alkaline-acidic media, in which one electrode is alkaline and the other acidic, is the focus of this study.

In the present work, ethanol is used as a fuel to study the performance of MLSPCFC. Pure ethanol has an energy density of $8028 \mathrm{Wh} / \mathrm{g}$ [8], as compared with the Li ion battery at $350-470 \mathrm{Wh} \cdot \mathrm{L}^{-1}$ [9]. As well as Table 1 shows that the ethanol has higher energy density compared to methanol and formic acid fuel cell. Ethanol is an accepted, more attractive, and promising clean and energy-efficient cell [10]. Ethanol is a carbon-neutral, sustainable fuel that can be produced in great quantity through the fermentation of agricultural products or biomass. But its many unique properties including low toxicity, ease in handling and transportation make it a fuel of choice compared to other fuel cells [11].

A few studies were carried out that attempted to use oxygen solution as the oxidant. The performance of these microfuel cells was found to be severely hampered by the low transport efficiency of oxygen in the cathode stream.

Membraneless sodium percarbonate fuel cell (MLSPCFC) is studied in this work using an acidic solution of sodium percarbonate $\left(2 \mathrm{Na}_{2} \mathrm{CO}_{3} \cdot 3 \mathrm{H}_{2} \mathrm{O}_{2}\right)$ as the oxidant. The impact of using alkaline-acidic media (i.e., one electrode is acidic and the other one is alkaline condition) on the performance of the fuel cell is the focus of our study. Sodium percarbonate, the oxidant used in the study, is cost-effective, environmentally friendly, and nontoxic industrial chemical used on a large scale in detergents and as a mild oxidant. Sodium percarbonate, a true peroxo salt, proves to be a convenient source of hydrogen peroxide $[12,13]$ :

$$
2 \mathrm{Na}_{2} \mathrm{CO}_{3} \cdot 3 \mathrm{H}_{2} \mathrm{O}_{2} \longrightarrow 2 \mathrm{Na}_{2} \mathrm{CO}_{3}+3 \mathrm{H}_{2} \mathrm{O}_{2}
$$

Sodium percarbonate functions as both an oxidant and reductant, which makes this cell unique when compared with other fuel cells using $\mathrm{H}_{2} \mathrm{O}_{2}[14,15]$. The performance of MLSPCFC in generating electric power is comparable to a typical air-breathing DMFC that operates in a microchemical channel at room temperature. The issues arising out of using a membrane cell, as explained before, can be avoided when a MLSPCFC is employed. Another advantage of using MLSPCFC is the simple structure of the cell in the absence of membrane electrode assemblies in addition to a reduction in the cost of materials.

Using a bipolar electrolyte increases fuel utilisation and produces a higher potential when compared to the acid and alkaline fuel cell, and also there has been a considerable focus on the alkaline-acidic fuel cell in the recent past [16]. This work also explains the bipolar electrolyte membraneless sodium percarbonate fuel cell as it operates at room temperature.

In this study, new forms of simplified architectures, unique from those that have been reported in the literature, have been developed by eliminating and integrating the key components of a conventional MEA. With these advantages, we believe membraneless sodium percarbonate fuel cells (MLSPCFC) can be used as an alternative for portable power applications.

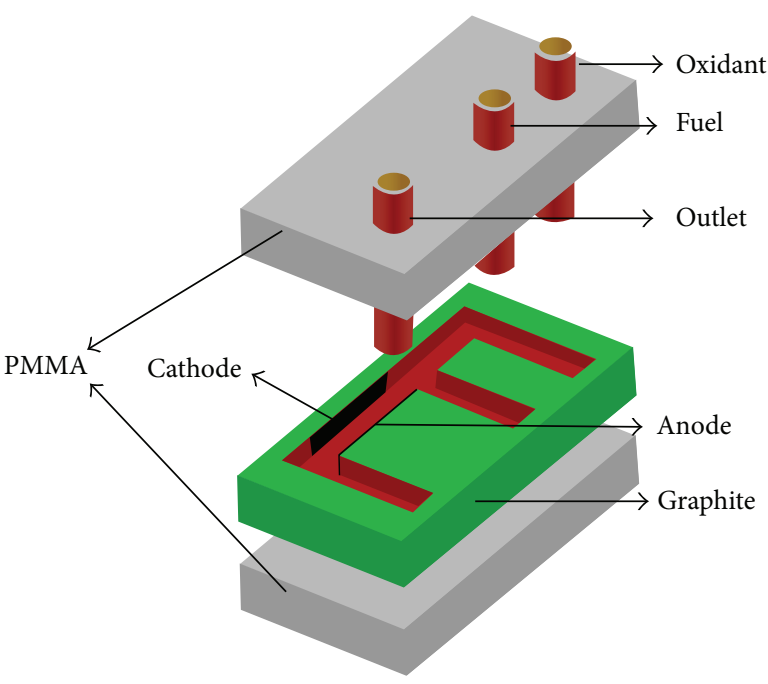

FIGURE 1: Schematic of the E-shaped membraneless laminarflow-based fuel cell with graphite plates molded with PDMS poly(dimethylsiloxane) and sealed with PMMA poly(methyl methacrylate).

\section{Experimental}

2.1. Materials and Reagents. All experiments were conducted at room temperature using ethanol (98\%, Merck) in deionized water as the fuel and sodium percarbonate (99\%, Riedel) dissolved in $1 \mathrm{M}$ sulfuric acid (98\%, Merck) or $1 \mathrm{M}$ potassium hydroxide (98\%, Merck) in deionized water as the oxidant.

2.2. Catalyst Preparation. For all the experiments involving MLSPCFC, unsupported platinum black nanoparticles (Alpha Aesar) are applied to the sides of the graphite plates (kiriti graphite), which act as the cathode and anode that line the microfluidic channel. The catalyst suspensions for both anode and cathode were prepared by mixing Pt black nanoparticles at a concentration of $6.0 \mathrm{mg} \mathrm{mL}^{-1}$ in a $10 \mathrm{wt} . \%$ Nafion solution (Nafion stock solution: Dupont, 5\% (w/w) solution). This mixture was sonicated and applied to the side faces of the graphite plates at a loading of $2 \mathrm{mg} \mathrm{cm}^{-2}$. Then the solvent was evaporated by the use of a heat lamp for uniform loading.

2.3. Design of Membraneless Ethanol Fuel Cell. In MLSPCFC, an E-shaped laminar flow channel with catalyst-coated graphite plates of $1 \mathrm{~mm}$ thickness is used (Figure 1). On subsequent deposition of catalyst to the cathode and anode, the E-shaped microfluidic channel structure is molded with poly(dimethylsiloxane) (PDMS; chemsworth), typically 1$10 \mathrm{~mm}$ in thickness, and finally sealed with a solid substrate, such as $2 \mathrm{~mm}$ thick pieces of poly(methyl methacrylate) (PMMA; 92\% G.khanna \& Co), to provide rigidity and supportive strength to the layered system. Silicon tubing (Shree Gaurav Rubber Products) is used to guide the fuel and oxidant into the E-shaped channel systems at the top and to let the waste stream out at the bottom of the channel. 
TABLE 1: The summary of thermodynamic data and theoretical energy densities for various fuels.

\begin{tabular}{lccccc}
\hline Fuel & $n(\mathrm{e})$ & $\begin{array}{c}-\Delta H^{\circ} \\
(\mathrm{kJ} / \mathrm{mol})\end{array}$ & $\begin{array}{c}-\Delta G^{\circ} \\
(\mathrm{kJ} / \mathrm{mol})\end{array}$ & $\begin{array}{c}\text { Gravimetric energy } \\
\text { density }(\mathrm{Wh} . / \mathrm{kg})\end{array}$ & $\begin{array}{c}\text { Volumetric energy } \\
\text { density }(\mathrm{Wh} . / \mathrm{kg})\end{array}$ \\
\hline Ethanol & 12 & 277.7 & 174.9 & 6100 & 7850 \\
Borohydride & 8 & 1392 & 1267 & 2925 & 2840 \\
Methanol & 6 & 726.6 & 702.5 & 4690 & 6400 \\
Formic acid & 2 & 270.3 & 285.5 & 2086 & 1710 \\
\hline
\end{tabular}

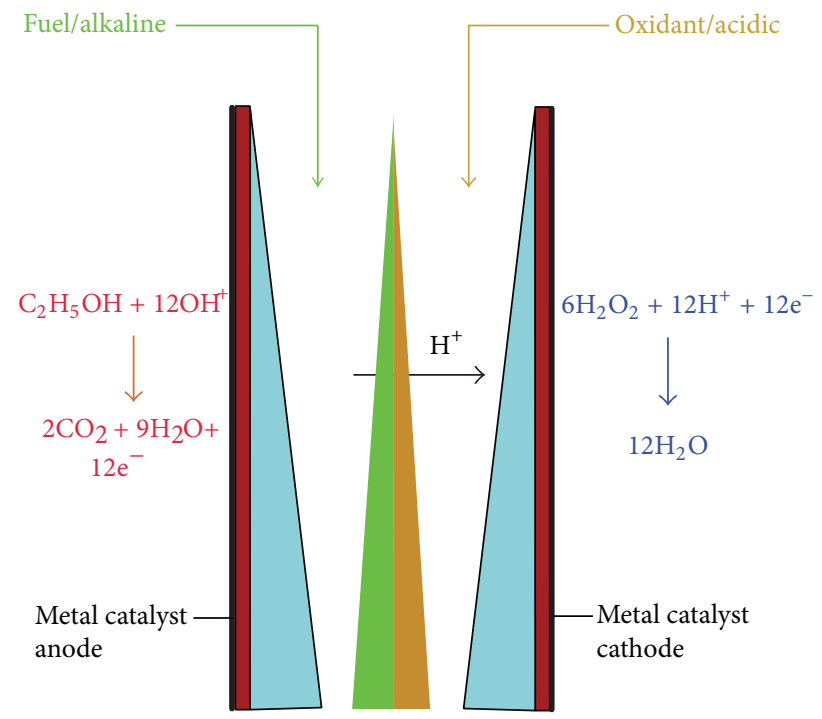

FIGURE 2: A cross-section of channel showing depletion boundary layer over anode and cathode metal catalyst and interdiffusion zone at the liquid-liquid interface with vertical electrodes on side walls.

2.4. Testing the Fuel Cell. The fuel and oxidant solutions were pumped through the device using a syringe pump (Schiller India). The flow rate of each of the streams was $0.3 \mathrm{~mL} \mathrm{~min} \mathrm{mi}^{-1}$ (total flow rate of $0.6 \mathrm{~mL} \mathrm{~min}{ }^{-1}$ ) with a velocity of $2 \mathrm{~cm} \mathrm{~s}^{-1}$ [7]. Also, the cell was allowed to work for an hour to enable the flow to reach a steady state. When injected through the inlets, the fuel and oxidant solutions merge at the E-junction and continue to exhibit a laminar flow in parallel without turbulent mixing, if the system is characterised by a Reynolds number, $\operatorname{Re} \leqslant 2100$ [17], over the anode and cathode, where fuel and oxidant are allowed to be oxidised and reduced, respectively, as shown in Figure 2.

Cell measurements were recorded using a CS310 computer-controlled potentiostat (Zhengzhou Triangle Instrument Co. Ltd.) with the associated Thales $\mathrm{Z}$ software package. For each analysed factor, the performance of the fuel cell was evaluated by recording the cell polarisation and obtaining the corresponding power density curves. Consequently, the microfluidic cell was found to keep these fluids stable without a separation membrane.

\section{Results and Discussion}

We tested the cell for two objectives. The first step consisted in analyzing the flexibility and the performance implications of operating membraneless sodium percarbonate fuel cell (MLSPCFC) in an alkaline-acidic media and the subsequent second step was intended to further improve the cell performance by characterising the main cell by changing several operational parameters, such as fuels compositions, oxidant compositions, electrolyte compositions, distance effect, and flow rate, and to observe their influence on the polarisation behaviour of the cell.

3.1. Media Flexibility of MLSPCFC. In recent years, the effect of operating laminar-flow-based fuel cells in all-acidic, allalkaline, and alkaline-acidic media has received considerable attention $[18,19]$. Since certain hydrocarbons such as ethanol, methanol, and formic acid can easily be stored in a liquid form under ambient conditions, they are known to generate high energy densities in a safe manner.

The MLSPCFC is flexible in the use of media such as allacid, all-alkaline, or in an alkaline-acidic media, in which the anode is exposed to acidic media, while the cathode is exposed to alkaline media or vice versa. The performance of MLSPCFC in alkaline-acidic media, using an alkaline anode and an acidic cathode, has been found to result in a higher overall cell potential than that possible from all-acidic and all-alkaline fuel cell experiments.

\subsection{Performance of MLSPCFC in All-Acidic and All-Alkaline} Media. The $\mathrm{pH}$ of the electrolyte influences reaction kinetics at the individual electrodes, as well as the electrode potential at which oxidation or reduction occurs [20-24]. Equations (2) and (3) represent the half-cell reactions and standard electrode potentials of ethanol oxidation and peroxide reduction in acidic media and (5) and (6) represent the alkaline media. Equations (4) and (7) represent the overall cell reaction, in all-acid or all-alkaline media. The alkaline-alkaline media and the acidic-acidic media have a maximum theoretical open circuit potential (OCP) of $1.726 \mathrm{~V}$ and $1.695 \mathrm{~V}$. On the other hand, we use alkaline-acidic media to force reactions (3) and (6) to proceed with the aim of improving fuel cell performance.

Ethanol/percarbonate in acidic media is as follows:

$$
\begin{aligned}
& \text { Anode: } \mathrm{C}_{2} \mathrm{H}_{5} \mathrm{OH}+3 \mathrm{H}_{2} \mathrm{O} \\
& \longrightarrow 2 \mathrm{CO}_{2}+12 \mathrm{H}^{+}+12 \mathrm{e}^{-} \quad \mathrm{E}^{\circ}=0.085 \mathrm{~V} \\
& \text { Cathode: } 6 \mathrm{H}_{2} \mathrm{O}_{2}+12 \mathrm{H}^{+}+12 \mathrm{e}^{-} \\
& \longrightarrow 12 \mathrm{H}_{2} \mathrm{O} \quad \mathrm{E}^{\circ}=1.78 \mathrm{~V}
\end{aligned}
$$




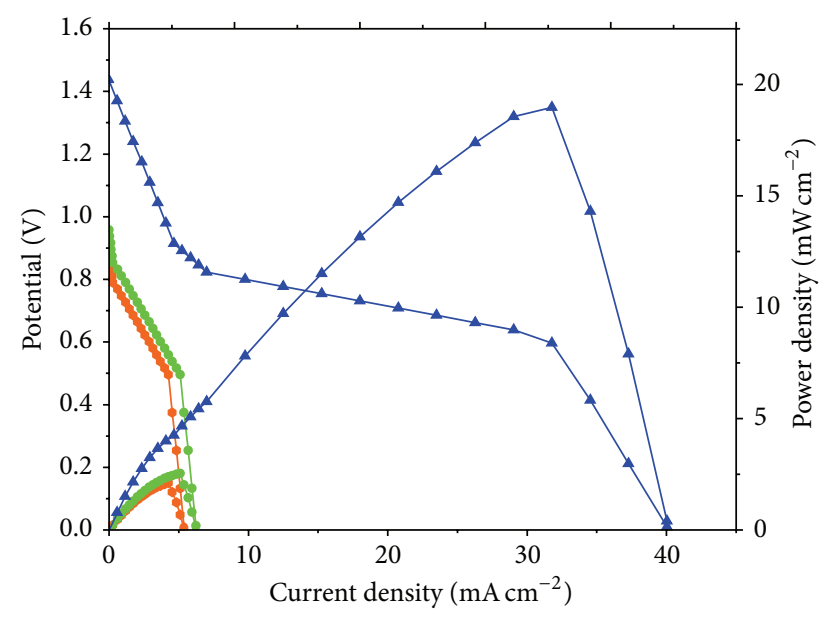

$\rightarrow$ (a) All acidic

$\rightarrow$ (b) All alkaline

$\_$(c) Acid/alkaline

FIgURE 3: Performance of media flexibility on current and power density of MLSPCFC at room temperature. (a) All alkaline media ([Fuel]: $1 \mathrm{M}$ ethanol $+1 \mathrm{M} \mathrm{KOH}$. [Oxidant]: $0.1 \mathrm{M}$ percarbonate + $1 \mathrm{M} \mathrm{KOH}$ ). (b) All acidic media ([Fuel]: $1 \mathrm{M}$ ethanol $+1 \mathrm{M} \mathrm{H}_{2} \mathrm{SO}_{4}$. [Oxidant]: $0.1 \mathrm{M}$ percarbonate $+1 \mathrm{M} \mathrm{H}_{2} \mathrm{SO}_{4}$ ). (c) Alkaline-acidic media ([Fuel]: $1 \mathrm{M}$ ethanol $+1 \mathrm{M} \mathrm{KOH}$. [Oxidant]: $0.1 \mathrm{M}$ percarbonate $\left.+1 \mathrm{M} \mathrm{H}_{2} \mathrm{SO}_{4}\right)$.

$$
\text { Overall: } \begin{aligned}
& \mathrm{C}_{2} \mathrm{H}_{5} \mathrm{OH}+6 \mathrm{H}_{2} \mathrm{O}_{2} \\
& \longrightarrow 2 \mathrm{CO}_{2}+9 \mathrm{H}_{2} \mathrm{O} \quad \mathrm{E}^{\circ}=1.695 \mathrm{~V}
\end{aligned}
$$

Ethanol/Percarbonate in alkaline media is as follows:

$$
\begin{aligned}
& \text { Anode: } \mathrm{C}_{2} \mathrm{H}_{5} \mathrm{OH}+12 \mathrm{OH}^{-} \\
& \longrightarrow 2 \mathrm{CO}_{2}+9 \mathrm{H}_{2} \mathrm{O}+12 \mathrm{e}^{-} \quad \mathrm{E}^{\circ}=-0.74 \mathrm{~V} \\
& \text { Cathode: } 6 \mathrm{H}_{2} \mathrm{O}_{2}+12 \mathrm{e}^{-} \longrightarrow 12 \mathrm{OH}^{-} \quad \mathrm{E}^{\circ}=0.986 \mathrm{~V} \\
& \text { Overall: } \mathrm{C}_{2} \mathrm{H}_{5} \mathrm{OH}+6 \mathrm{H}_{2} \mathrm{O}_{2} \\
& \longrightarrow 2 \mathrm{CO}_{2}+9 \mathrm{H}_{2} \mathrm{O} \quad \mathrm{E}^{\circ}=1.726 \mathrm{~V}
\end{aligned}
$$

A comparison of the performance of an MLSPCFC in all-alkaline and all-acidic media is shown in Figure 3. Initially at low current densities, both the polarisation curves are identical and thus it is clear that the performance of MLSPCFC is independent of the medium. The mass transport limitation region is around $6 \mathrm{~mA} \mathrm{~cm}^{-2}$ in the MLSPCFC in both alkaline and acidic media and was in good agreement with the previous study [25]. The MLSPCFC worked for several days without any drop in its performance in a vast array of test conditions. No issues with carbonate formation were encountered in this MLSPCFC at room temperature, as any carbonate that does form is immediately removed from the system by the flowing streams.

3.3. Performance of MLSPCFC in Acidic-Alkaline Media: Acidic Anode and Alkaline Cathode. The performance of MLSPCFC using a fuel stream of $1 \mathrm{M}$ ethanol in $1 \mathrm{M} \mathrm{H}_{2} \mathrm{SO}_{4}$ and an oxidant stream of $0.1 \mathrm{M}$ percarbonate in $1 \mathrm{M} \mathrm{KOH}$ was investigated. The measurements were carried out at room temperature for two configurations: (i) acidic-alkaline media: acidic anode, alkaline cathode, and (ii) alkaline-acidic media: alkaline anode, acidic cathode. In alkaline-acidic media of this kind, the neutralisation reaction of $\mathrm{OH}^{-}$and $\mathrm{H}^{+}$to form water occurs at the liquid-liquid interface between the fuel and the oxidant streams. In the first configuration, the overall cell reaction, (10), can be obtained from (2) and (6) as follows.

Mixed media 1: acidic anode and alkaline cathode:

$$
\begin{aligned}
& \text { Anode: Equation (2) } \\
& \text { Cathode: Equation (6) }
\end{aligned}
$$

Overall: $\mathrm{C}_{2} \mathrm{H}_{5} \mathrm{OH}+6 \mathrm{H}_{2} \mathrm{O}_{2}+3 \mathrm{H}_{2} \mathrm{O}$

$$
\longrightarrow 2 \mathrm{CO}_{2}+12 \mathrm{H}^{+}+12 \mathrm{OH}^{-} \quad \mathrm{E}^{\circ}=0.901 \mathrm{~V}
$$

In this alkaline-acidic media, the maximum theoretical OCP that can be obtained is $0.901 \mathrm{~V}$. The energy liberated in ethanol oxidation and peroxide reduction reactions is mostly consumed for ionisation of water. In this configuration, the coexistence of the galvanic and ethanol electrolytic reactions has been found to be the reason for a very low yield of energy, and therefore they were not studied any further.

3.4. Performance of MLSPCFC in Alkaline-Acidic Media: Alkaline Anode and Acidic Cathode. In alkaline-acidic media, the MLSPCFC functions using a fuel stream of an alkaline anode and an acidic cathode, which allows energy to be obtained both from the ethanol oxidation/peroxide reduction reactions and from the acid/alkali electrochemical neutralisation reactions, as evident from the overall cell reaction equation (13).

Mixed media 2: alkaline anode and acidic cathode:

$$
\text { Anode: Equation (5) }
$$

Cathode: Equation (3)

$$
\text { Overall: } \begin{aligned}
\mathrm{C}_{2} \mathrm{H}_{5} \mathrm{OH}+6 \mathrm{H}_{2} \mathrm{O}_{2}+12 \mathrm{H}^{+}+12 \mathrm{OH}^{-} \\
\longrightarrow 2 \mathrm{CO}_{2}+21 \mathrm{H}_{2} \mathrm{O} \quad \mathrm{E}^{\circ}=2.52 \mathrm{~V}
\end{aligned}
$$

In this alkaline-acidic media, the combination of two galvanic reactions yields a desirable high theoretical OCP of $2.52 \mathrm{~V}$. Note that the inherent value of the electromotive force of the MLSPCFC is higher than that of the HFC (1.23 V) and the PEMFC or DMFC (1.21 V). However, because of the overpotentials resulting from the slow kinetics of peroxide reduction and ethanol oxidation, the OCP gets reduced to a measured value of $1.43 \mathrm{~V}$ as shown in Figure 3, which was in good agreement with the previous reported value of $1.4 \mathrm{~V}$ [25]. In alkaline-acidic media, both $\mathrm{OH}^{-}$and $\mathrm{H}^{+}$are consumed at the anode and cathode, respectively, at a rate of six ions for each molecule of ethanol.

In alkaline-acidic media, in which an alkaline anode and an acidic cathode are used, a higher overall cell potential was realised compared to that obtained for the all-acidic and allalkaline MLSPCFC experiments. Figure 3 shows the power 
TABLE 2: Effect of medium on the performance of the MLSPCFC.

\begin{tabular}{lccc}
\hline & $\begin{array}{c}\text { All- } \\
\text { alkaline }\end{array}$ & $\begin{array}{c}\text { All- } \\
\text { acidic }\end{array}$ & $\begin{array}{c}\text { Alkaline- } \\
\text { acidic }\end{array}$ \\
\hline $\begin{array}{l}\text { Open circuit voltage (V) } \\
\begin{array}{l}\text { Short-circuit current density } \\
\left(\mathrm{mA} \mathrm{cm}^{-2}\right)\end{array}\end{array}$ & 0.95 & 0.89 & 1.43 \\
$\begin{array}{l}\text { Peak power density } \\
\left(\mathrm{mW} \mathrm{cm}^{-2}\right)\end{array}$ & 6.23 & 5.38 & 40.03 \\
$\begin{array}{l}\text { Cell voltage at peak power } \\
\text { density (V) }\end{array}$ & 0.49 & 0.50 & 0.59 \\
$\begin{array}{l}\text { Current density at peak power } \\
\text { density (mW cm }\end{array}$ & 5.11 & 4.26 & 31.76 \\
\hline
\end{tabular}

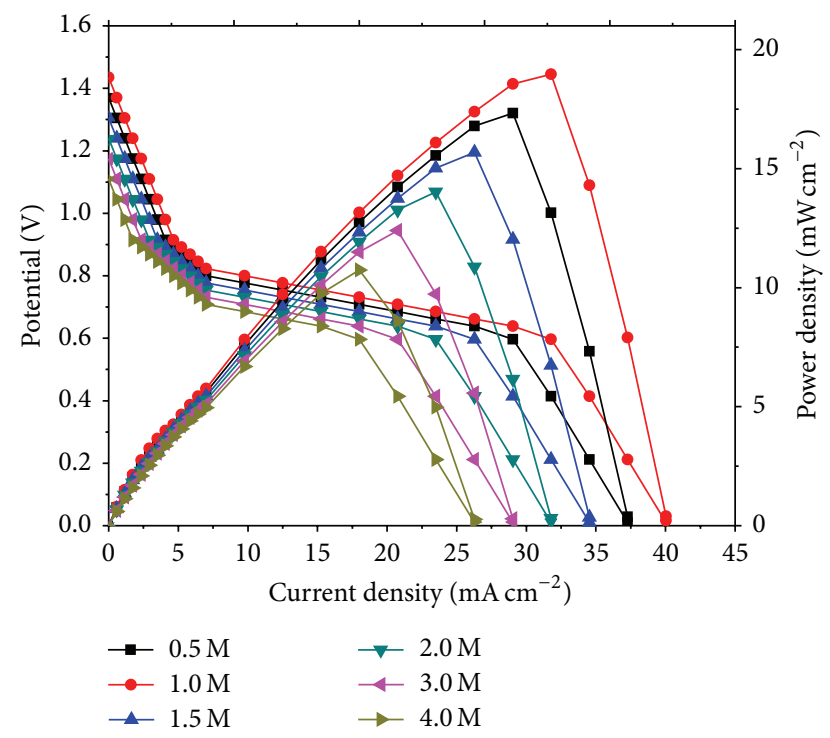

FIGURE 4: Effect of ethanol concentration on the current and power density of the MLSPCFC at room temperature. ([Fuel]: $x \mathrm{M}$ ethanol $+1 \mathrm{M} \mathrm{KOH}$. [Oxidant]: $0.1 \mathrm{M}$ percarbonate $\left.+1 \mathrm{M} \mathrm{H}_{2} \mathrm{SO}_{4}\right)$.

density curves of the MLSPCFC experiments performed using different media combinations at the anode and cathode.

When all-acidic and all-alkaline are used, the maximum power densities generated by the MLSCFC are 2.11 and $2.53 \mathrm{~mW} \mathrm{~cm}^{-2}$, respectively, both at a cell potential of about $0.5 \mathrm{~V}$, whereas when an alkaline-acidic media is used, it results in a power density maximum of $18.96 \mathrm{~mW} \mathrm{~cm}^{-2}$ at a cell potential of about $0.5 \mathrm{~V}$. The alkaline-acidic media fuel cell clearly outperforms both the all-acidic and all-alkaline fuel cell (Table 2). The higher power densities in the MLSPCFC using alkaline-acidic media result from higher overall cell potentials due to the unprecedented ability to operate the cathode and anode at different $\mathrm{pH}$ values in an MLSPCFC.

3.5. Influence of Fuel Composition. The effect of fuel on the performance of MLSPCFC was analysed by varying the concentration of ethanol between 0.5 and $4 \mathrm{M}$ (Figure 4).

The effect of the fuel concentration on the product selectivity was studied by varying both ethanol and $\mathrm{KOH}$ concentrations. The effect of ethanol concentration was investigated by varying the concentration of ethanol from 0.5 , $1.0,1.5,2.0,3.0$ to $4.0 \mathrm{M}$, while fixing the concentration of $\mathrm{KOH}$ at 1.0 M. Similarly, the effect of $\mathrm{KOH}$ concentration was observed by varying the concentration of $\mathrm{KOH}$ from $0.5,1.0$, 1.5 to $2.0 \mathrm{M}$, while fixing the concentration of ethanol at $1.0 \mathrm{M}$. Among these several combinations of fuel and oxidant, the fuel solution containing $1.0 \mathrm{M}$ ethanol and 1.0 M KOH gives the highest and most stable performance, and a decrease and fluctuation of cell voltage was observed as the ethanol and $\mathrm{KOH}$ concentrations are varied.

The experimental results show that the fuel cell performance decreases as the ethanol concentration increases. This decreasing trend in cell performance at higher ethanol concentrations can be explained as resulting from (a) creation of mixed potential at the cathode due to fuel crossover; (b) kinetic decrease in anode; (c) transport resistance increase at the anode; and (d) ohmic resistance increase.

In a fluidic system, fuel crossover can create mixed potentials, decrease in cell efficiency, and could even deactivate the catalyst. Fortunately, the device design and operating parameters can both be controlled to prevent fuel crossover [26, 27] in any membraneless fuel cell; therefore, the higher ethanol concentration is not the cause of decrease of performance in a fuel cell. The kinetic decrease in the anode also cannot be a factor because the electrooxidation of ethanol on $\mathrm{Pt}$ has a positive reaction order between 0.5 and $1 \mathrm{M}$. Thus, the activity at the anode increases initially as the concentration of fuel increases. Therefore, the anode is not limited by kinetic performance at higher ethanol concentrations. Taking into account these factors, the ethanol concentration of $1 \mathrm{M}$ seems to be the best composition for the fuel and so this value was fixed for the remaining experiments.

3.6. Influence of Oxidant Composition. The effects of percarbonate concentration on the cell performance were investigated at $0.01,0.025,0.05,0.075$, and $0.1 \mathrm{M}$. The power density increased as sodium percarbonate concentration increases in the MLSPCFC system and reaches the maximum of $1.43 \mathrm{~V}$ at $0.1 \mathrm{M}$ sodium percarbonate. Peak power densities of $1.74,3.12$, $5.83,12.39$, and $18.96 \mathrm{~mW} \mathrm{~cm}^{-2}$ were obtained at $0.01,0.025$, $0.05,0.075$, and $0.1 \mathrm{M}$ of sodium percarbonate, respectively (Figure 5). A further increase in the oxidant concentration shows no improvement in the cell performance. Therefore, the value of $0.1 \mathrm{M}$ has been fixed as the percarbonate concentration in the oxidant solution.

Likewise, the effect of $\mathrm{H}_{2} \mathrm{SO}_{4}$ concentration in the oxidant solution has also been analysed. The concentration of $\mathrm{H}_{2} \mathrm{SO}_{4}$ was varied between 0.1 and $1.0 \mathrm{M}$. The maximum power density $\left(18.96 \mathrm{~mW} \mathrm{~cm}^{-2}\right)$ was obtained at $1 \mathrm{M} \mathrm{H}_{2} \mathrm{SO}_{4}$ (Figure 6). A further increase in the concentration of $\mathrm{H}_{2} \mathrm{SO}_{4}$ shows no improvement in the cell performance. Therefore, the value of $1 \mathrm{M}$ has been fixed as the $\mathrm{H}_{2} \mathrm{SO}_{4}$ concentration in the oxidant solution.

3.7. Influence of Distance Effect on the Performance of $M L S P C F C$. In order to analyse the potential benefit arising from a reduced diffusion length of the reacting species moving between the anode and cathode, the distances were 


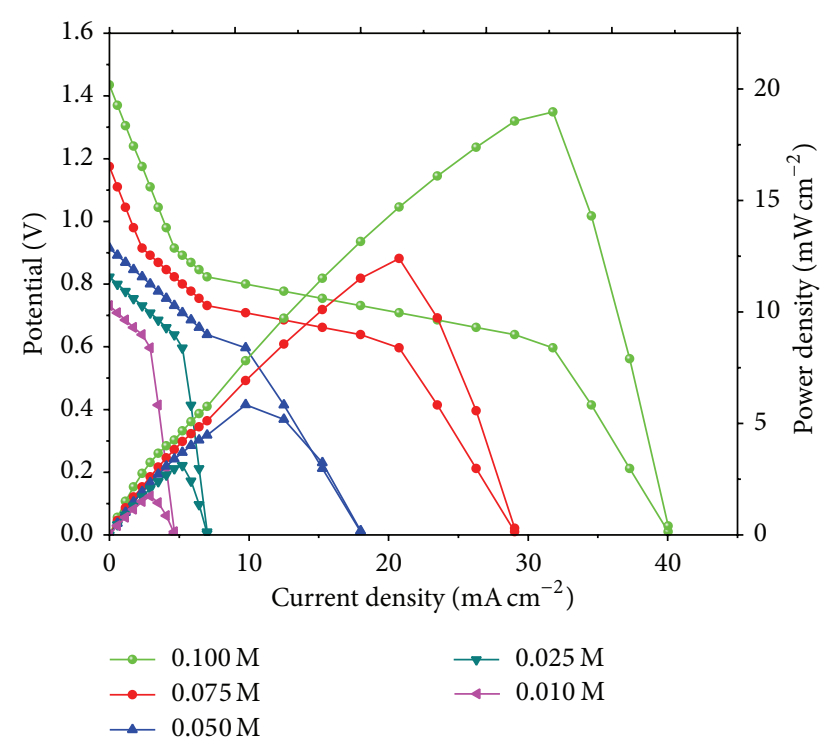

FIGURE 5: Effect of percarbonate concentration on the current and power density of the MLSPCFC at room temperature. ([Fuel]: $1 \mathrm{M}$ ethanol $+1 \mathrm{M} \mathrm{KOH}$. [Oxidant]: $x \mathrm{M}$ percarbonate $\left.+1 \mathrm{M} \mathrm{H}_{2} \mathrm{SO}_{4}\right)$.

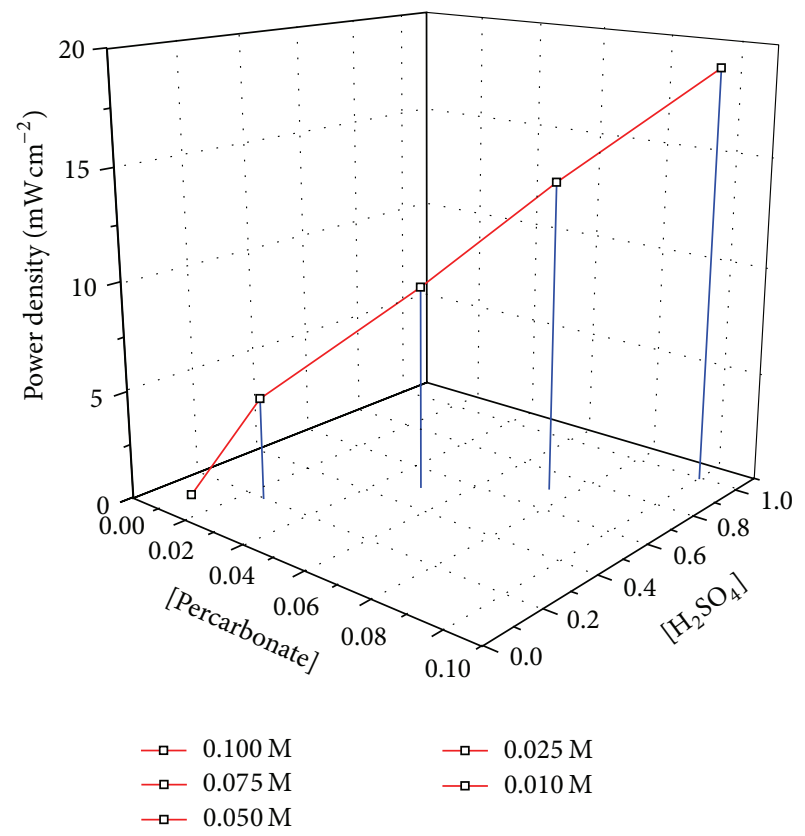

FIGURE 6: Effect of various combinations of percarbonate and sulphuric acid concentrations on the maximum power density $\left(18.96 \mathrm{~mW} \mathrm{~cm}^{-2}\right)$ of the MLSPCFC at room temperature. The fuel mixture for variation of oxidant is ([fuel]: $1 \mathrm{M}$ ethanol $+1 \mathrm{M} \mathrm{KOH}$, [oxidant]: $x \mathrm{M}$ percarbonate $+1 \mathrm{M} \mathrm{H}_{2} \mathrm{SO}_{4}$ ) and the fuel mixture for variation of sulphuric acid is ([fuel]: $1 \mathrm{M}$ ethanol $+1 \mathrm{M} \mathrm{KOH}$, [oxidant]: $0.1 \mathrm{M}$ percarbonate $\left.+x \mathrm{M} \mathrm{H}_{2} \mathrm{SO}_{4}\right)$.

varied between 1 and $100 \mathrm{~mm}$. When the distance between the anode and cathode decreased, the maximum power density was observed, as shown in Figure 7. Considering the role of a charge carrier, a shorter diffusion length is believed to result in a faster electrochemical reaction because the diffusion time of reacting species would be shorter. This leads

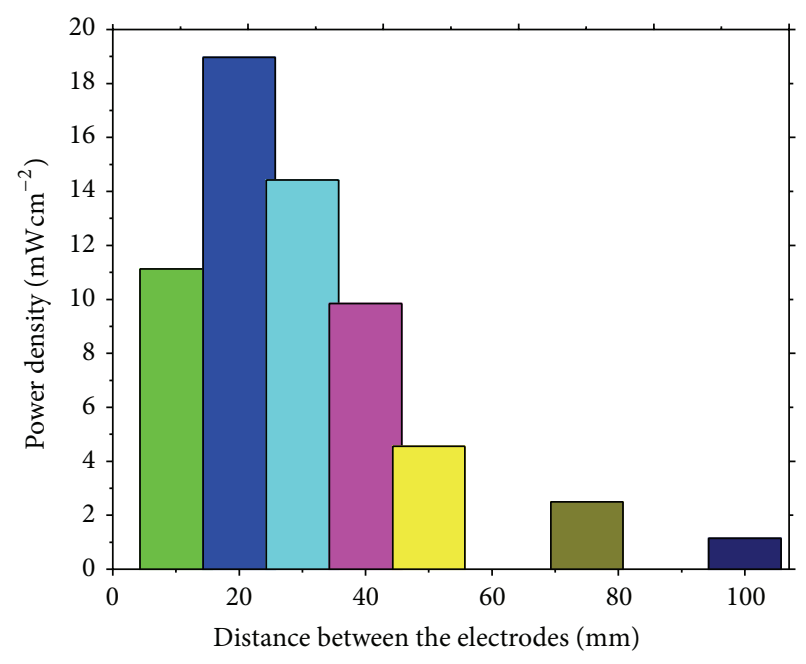

FIGURE 7: Effect of distance between anode and cathode on the maximum power density of the MLSPCFC at room temperature. ([Fuel]: $1 \mathrm{M}$ ethanol $+1 \mathrm{M} \mathrm{KOH}$. [Oxidant]: $0.1 \mathrm{M}$ percarbonate + $1 \mathrm{M} \mathrm{H}_{2} \mathrm{SO}_{4}$ ).

to more reactions taking place at a given time, which increases the total number of charges involving the electrochemical reactions at the anode and cathode. This finding provides a good evidence for the presence of a charge carrier moving between the anode and cathode in the fuel mixture to complete redox reactions of the fuel cell [28].

3.8. Influence of Fuel Mixture Flow Rate. Since maximum power density is dependent on the transport time of the reacting species, it can be controlled by the flow rate. In this experiment, flow rates of $0.1,0.3,0.5,0.7$, and $1.0 \mathrm{~mL} \mathrm{~min}^{-1}$ were tested. The cell potential and current were measured with different external loads as a function of the flow velocity of the fuel mixture. Using the flow rate applied and the cross-sectional area of the channel, a flow velocity can be calculated. In our experiments, the maximum power density was obtained at a flow rate of $0.3 \mathrm{~mL} \mathrm{~min}^{-1}$, after which the maximum power density decreases with an increase in the flow rate as shown in Figure 8. It is believed that more electrochemical reactions would take place at a given time and a greater output current could develop in the end.

\section{Conclusions}

A microscale membraneless sodium percarbonate fuel cell (MLSPCFC) was fabricated on PDMS and its performance was evaluated under different operating conditions. Standard microfabrication techniques were used to develop this device. Ethanol is used as a fuel at the anode and sodium percarbonate is used as an oxidant at the cathode in this membraneless fuel cell for the first time in an alkaline-acidic media. The experiments described in this study show that membraneless sodium percarbonate fuel cells are media flexible and they can be operated in all-acidic, all-alkaline, or even alkaline-acidic media. 


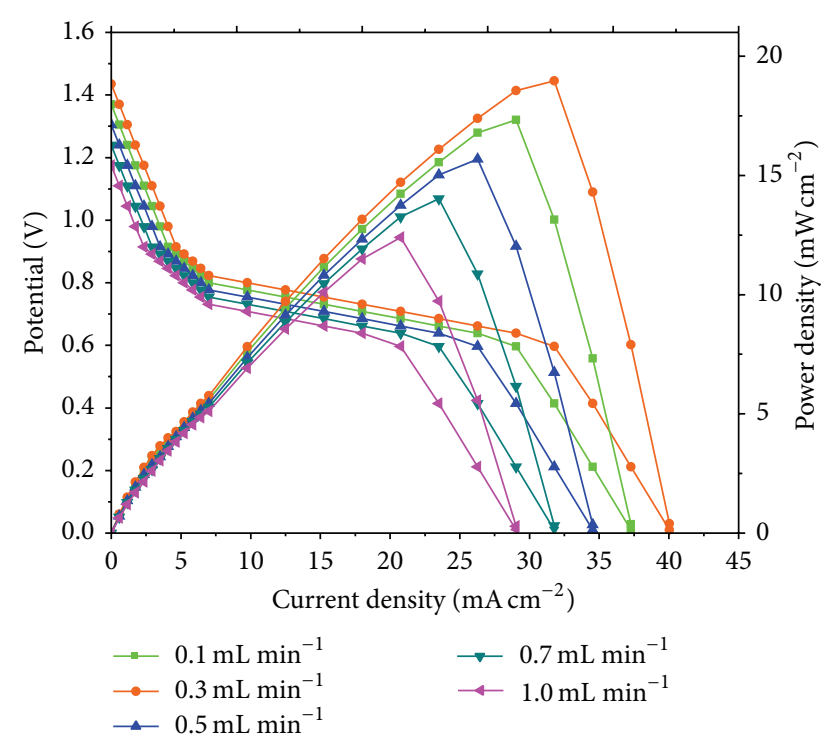

FIgURE 8: Effect of flow rate of fuel mixture on the current and power density of the MLSPCFC at room temperature. ([Fuel]: $1 \mathrm{M}$ ethanol + $1 \mathrm{M} \mathrm{KOH}$. [Oxidant]: $0.1 \mathrm{M}$ percarbonate + $1 \mathrm{M} \mathrm{H}_{2} \mathrm{SO}_{4}$ ).

In this work, we observed that the alkaline anode/acidic cathode alkaline-acidic media leads to a very high measured OCP of $1.43 \mathrm{~V}$, while other combinations result in very low OCPs as a result of the $\mathrm{pH}$ dependence of standard electrode potentials. For the MLSPCFC operating in the alkaline anode/acidic cathode alkaline-acidic media, the measured $\mathrm{OCP}$ of $1.43 \mathrm{~V}$ was found to be in a reasonable agreement with the theoretical OCP of $2.52 \mathrm{~V}$.

At room temperature, the laminar-flow-based microfluidic fuel cell produced a maximum power density of $18.96 \mathrm{~mW} \mathrm{~cm}^{-2}$ in the alkaline anode/acidic cathode alkaline-acidic media. We conclude that alkaline-acidic media MLSPCFC outperforms the all-acidic and all-alkaline MLSPCFCs. The effects of flow rates of the fuel and the oxidant and variation of concentrations of ethanol, percarbonate, and electrolytes were analysed in alkalineacidic media. The performance was characterised by $V-I$ curves and anode polarisation plots.

The results demonstrated that the performance of the developed membraneless fuel cell is significantly enhanced if the concentration of the oxidant in the cathodic stream is 10 times larger, and the current density is also increased approximately 10 times, whereas in the case of variation of ethanol concentration at the anode, fuel cell performance decreases as the ethanol concentration increases, due to the increase of ohmic resistance.

Thus, the present experimental findings have confirmed that the membraneless microfuel cell designed in our study is cathode limited and suggest that a crucial factor in improving cell performance is increasing the concentration of the oxidant in the cathodic stream. The flexibility of membraneless fuel cells to function with different media allowed for the successful working of mixed alkaline and acidic fuel cells.
The membraneless microfuel cell system investigated in this study seems to be a good candidate having many potential applications because its performance is comparable to an airbreathing DMFC.

In addition, the development of metal catalysts to accelerate the efficiency of MLSPCFC is in progress. Some further experimental studies focused on the microchannel design and the flow rate of MLSPCFC with various fuels will be beneficial to verify the predictions in this study and enable the practical utilisation of the cell in portable power sources.

The MLSPCFC has the advantages of a miniature size, simplicity of fabrication, use of aqueous fuel, and good cost efficiency. Furthermore, percarbonate is a cheap, nontoxic, stable, easily handled, environment-friendly, and large-scale industrial chemical and is a convenient source of hydrogen peroxide. We expect that the MLSPCFC may be a promising candidate for practical fuel cells to generate clean and sustainable energy in the future.

\section{Conflict of Interests}

The authors declare that there is no conflict of interests regarding the publication of this paper.

\section{References}

[1] L. Carrette, K. A. Friedrich, and U. Stimming, "Fuel cells: principles, types, fuels, and applications," ChemPhysChem, vol. 1, no. 4, pp. 163-193, 2000.

[2] E. R. Choban, P. Waszczuk, L. J. Markoski, A. Wieckowski, and P. J. A. Kenis, "Membraneless fuel cell based on laminar based on laminar flow," Fuel Cell, vol. 1728, pp. 261-265, 2003.

[3] E. R. Choban, L. J. Markoski, J. Stoltzfus, J. S. Moore, and P. J. A. Kenis, "Microfludic fuel cells that lack a PEM," Power Sources Proceedings, vol. 40, pp. 317-320, 2002.

[4] M. Eikerling, A. A. Kornyshev, A. M. Kuznetsov, J. Ulstrup, and S. Walbran, "Mechanisms of proton conductance in polymer electrolyte membranes," Journal of Physical Chemistry B, vol. 105, no. 17, pp. 3646-3662, 2002.

[5] R. S. Jayashree, L. Gancs, E. R. Choban et al., "Air-breathing laminar low-based microfluidic fuel cell," Journal of the American Chemical Society, vol. 127, no. 48, pp. 16758-16759, 2005.

[6] J. L. Cohen, D. A. Westly, A. Pechenik, and H. D. Abruña, "Fabrication and preliminary testing of a planar membraneless microchannel fuel cell," Journal of Power Sources, vol. 139, no. 1-2, pp. 96-105, 2005.

[7] A. Bazylak, D. Sinton, and N. Djilali, "Improved fuel utilization in microfluidic fuel cells: a computational study," Journal of Power Sources, vol. 143, no. 1-2, pp. 57-66, 2005.

[8] F. R. Brushett, R. S. Jayashree, W.-P. Zhou, and P. J. A. Kenis, "Investigation of fuel and media flexible laminar flow-based fuel cells," Electrochimica Acta, vol. 54, no. 27, pp. 7099-7105, 2009.

[9] G. Pistoia, Batteries for Portable Devices, Elsevier, New York, NY, USA, 2005.

[10] K. S. Roelofs and T. Schiestel, "sPEEK based composite membranes for direct ethanol fuel cell applications," Desalination, vol. 250, no. 3, pp. 1051-1052, 2010.

[11] S. Y. Shen, T. S. Zhao, and Q. X. Wu, "Product analysis of the ethanol oxidation reaction on palladium-based catalysts in 
an anion-exchange membrane fuel cell environment," International Journal of Hydrogen Energy, vol. 37, no. 1, pp. 575-582, 2012.

[12] F. A. Cotton and G. Wilkinson, Advanced Inorganic Chemistry, Wiley Interscience, New York, NY, USA, 1988.

[13] C. Karunakaran and R. Kamalam, "Structure-reactivity correlation of anilines in acetic acid," Journal of Organic Chemistry, vol. 67, no. 4, pp. 1118-1124, 2002.

[14] M. Gowdhamamoorthi, A. Arun, S. Kiruthika, and B. Muthukumaran, "Enhanced performance of membraneless sodium percarbonate fuel cells," Journal of Materials, vol. 2013, Article ID 548026, 7 pages, 2013.

[15] A. Arun, M. Gowdhamamoorthi, S. Kiruthika, and B. Muthukumaran, "Electrocatalyzed oxidation of methanol on carbon supported platinum electrode in membraneless sodium percarbonate fuel cells (MLSPCFC)," International Journal of ChemTech Research, vol. 5, no. 3, pp. 1152-1161, 2013.

[16] A. Arun, M. Gowdhamamoorthi, S. Kiruthika, and B. Muthukumaran, "Analysis of membraneless methanol fuel cell using percarbonate as an oxidant," Journal of the Electrochemical Society, vol. 161, no. 3, pp. F311-F317, 2014.

[17] T. J. Yen, N. Fang, X. Zhang, G. Q. Lu, and C. Y. Wang, "A micro methanol fuel cell operating at near room temperature," Applied Physics Letters, vol. 83, no. 19, pp. 4056-4058, 2003.

[18] L. An and T. S. Zhao, "Performance of an alkaline-acid direct ethanol fuel cell," International Journal of Hydrogen Energy, vol. 36, no. 16, pp. 9994-9999, 2011.

[19] L. An, T. S. Zhao, and J. B. Xu, "A bi-functional cathode structure for alkaline-acid direct ethanol fuel cells," International Journal of Hydrogen Energy, vol. 36, no. 20, pp. 13089-13095, 2011.

[20] J. S. Spendelow, G. Q. Lu, P. J. A. Kenis, and A. Wieckowski, "Electrooxidation of adsorbed $\mathrm{CO}$ on $\mathrm{Pt}(111)$ and $\mathrm{Pt}(111) / \mathrm{Ru}$ in alkaline media and comparison with results from acidic media," Journal of Electroanalytical Chemistry, vol. 568, no. 1-2, pp. 215224, 2004.

[21] G. F. McLean, T. Niet, S. Prince-Richard, and N. Djilali, "An assessment of alkaline fuel cell technology," International Journal of Hydrogen Energy, vol. 27, no. 5, pp. 507-526, 2002.

[22] T. Iwasita, "Electrocatalysis of methanol oxidation," Electrochimica Acta, vol. 47, no. 22-23, pp. 3663-3674, 2002.

[23] D. R. Lide, Ed., CRC Handbook of Chemistry and Physics, MARC Records Transmitter System, CRC Press, 85th edition, 2004.

[24] E. H. Yu and K. Scott, "Development of direct methanol alkaline fuel cells using anion exchange membranes," Journal of Power Sources, vol. 137, no. 2, pp. 248-256, 2004.

[25] E. R. Choban, J. S. Spendelow, L. Gancs, A. Wieckowski, and P. J. A. Kenis, "Membraneless laminar flow-based micro fuel cells operating in alkaline, acidic, and acidic/alkaline media," Electrochimica Acta, vol. 50, no. 27, pp. 5390-5398, 2005.

[26] R. F. Ismagilov, A. D. Stroock, P. J. A. Kenis, G. Whitesides, and H. A. Stone, "Experimental and theoretical scaling laws for transverse diffusive broadening in two-phase laminar flows in microchannels," Applied Physics Letters, vol. 76, no. 17, pp. 23762378, 2000.

[27] M. H. Chang, F. Chen, and N. Fang, "Analysis of membraneless fuel cell using laminar flow in a Y-shaped microchannel," Journal of Power Sources, vol. 159, no. 2, pp. 810-816, 2006.

[28] W. Sung and J. W. Choi, "A membraneless microscale fuel cell using non-noble catalysts in alkaline solution," Journal of Power Sources, vol. 172, no. 1, pp. 198-208, 2007. 

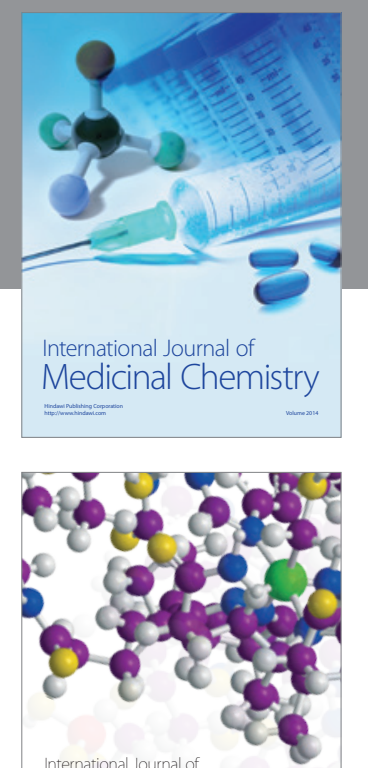

\section{Carbohydrate} Chemistry

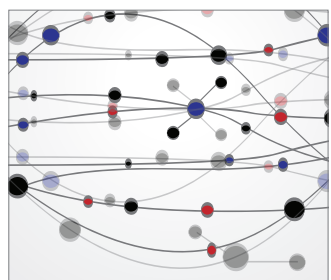

The Scientific World Journal
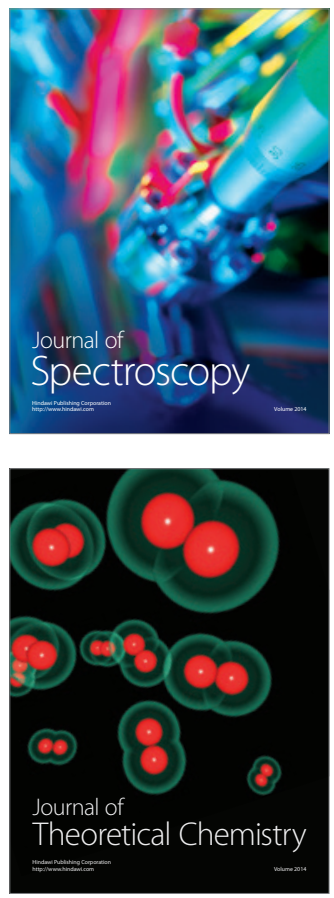
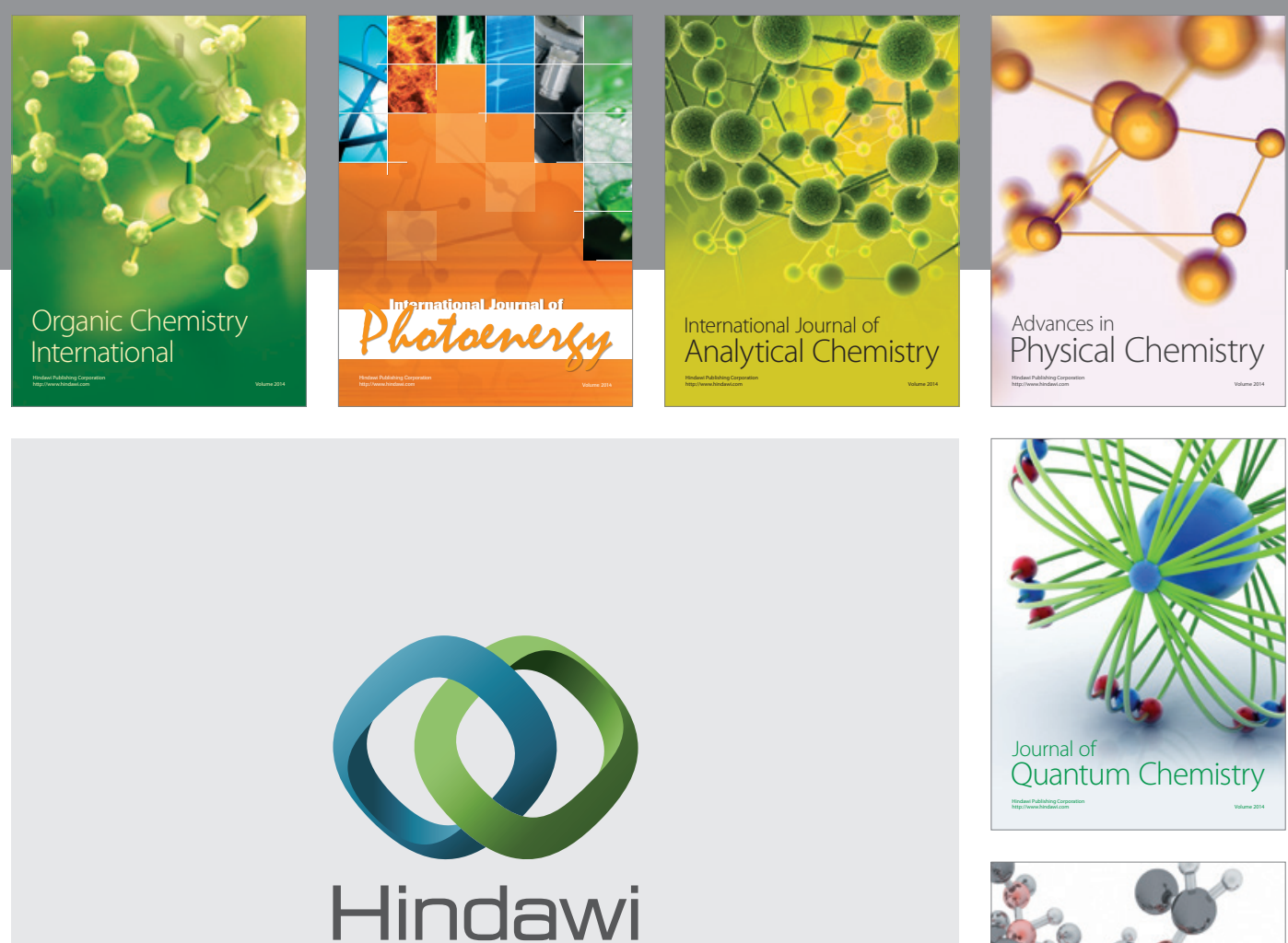

Submit your manuscripts at

http://www.hindawi.com

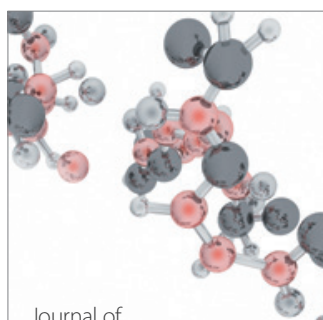

Analytical Methods

in Chemistry

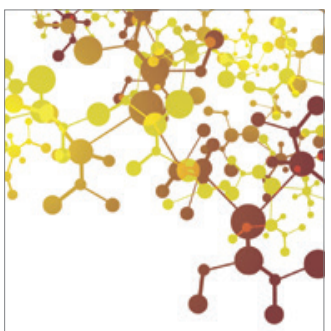

Journal of

Applied Chemistry

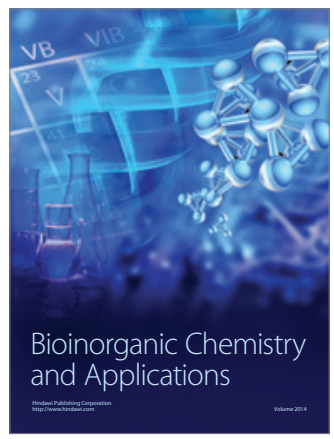

Inorganic Chemistry
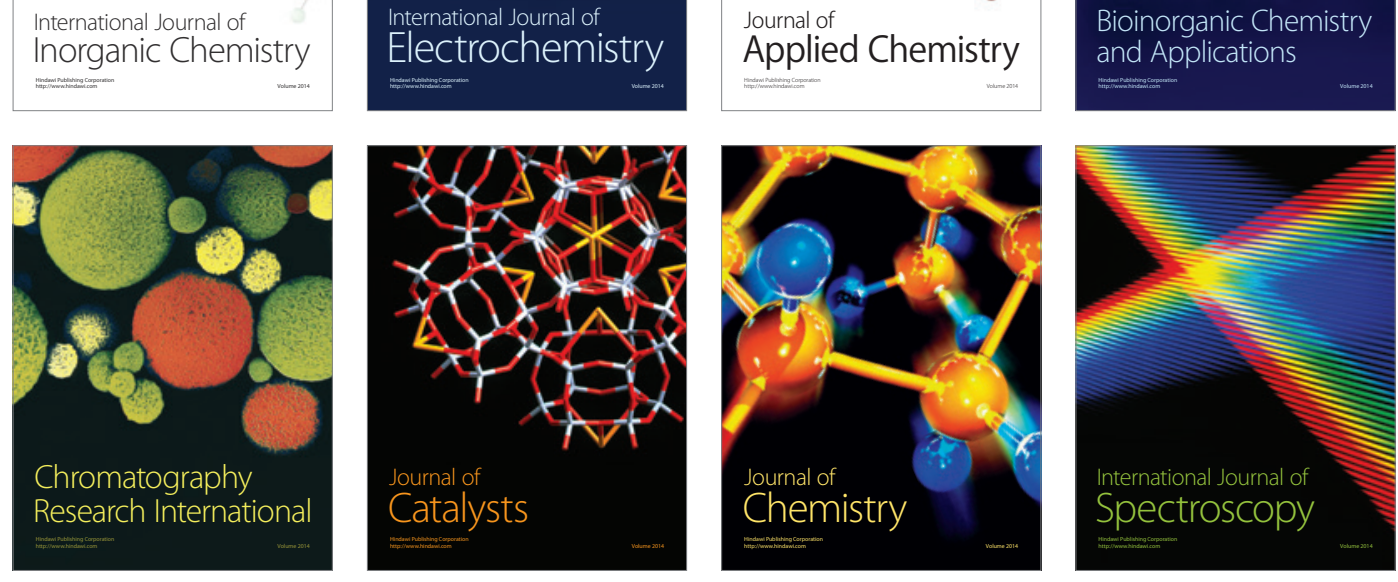